\title{
RESPON SISWA TERHADAP PEMBELAJARAN MENGGUNAKAN MODEL SIKLUS BELAJAR 5E BERBANTUAN MULTIMEDIA PADA MATERI KOLOID
}

\author{
Rody Putra Sartika \\ Pendidikan Kimia FKIP UNTAN \\ Jalan Prof. H. Hadari Nawawi Pontianak \\ e-mail: rodyputrasartika@yahoo.com
}

\begin{abstract}
This research aims to know students' response about learning process using learning cycle 5E model assisted with multimedia on colloid matter. Pre-experiment method with one-shot case study design was used regarding to this. There are 79 students of SMAN 7 Pontianak who involved in this research. indirect communication techniques was used to collect data. Based on the research is obtained very good student response to learning using the 5E learning cycle model of multimedia-assisted colloid matter. The information that is obtained from this research is a very good response of students to learning using the $5 E$ learning cycle model of multimedia-assisted colloid matter.
\end{abstract}

Keywords: learning cycle $5 E$ model, multimedia, students' response, colloid.

Abstrak:Penelitian ini bertujuan mengetahui respon siswa terhadap pembelajaran menggunakan model siklus belajar $5 E$ berbantuan multimedia pada materi koloid. Untuk menjawab permasalahan digunakan metode praeksperimen dengan desain one-shot case study. Sebanyak 79 siswa SMAN 7 Pontianak terlibat dalam penelitian ini. Teknik pengumpulan data menggunakan komunikasi tak langsung.Berdasarkan hasil penelitian diperoleh informasi bahwa respon siswasangat baik terhadap pembelajaran menggunakan model siklus belajar $5 E$ berbantuan multimedia pada materi koloid.

Kata-kata kunci:Model siklus belajar 5E, multimedia, respon siswa, koloid.

\section{PENDAHULUAN}

Kimia sebagai bagian dari sains seharusnya dapat memberikan suatu strategi yang menarik dan menyenangkan di dalam proses pembelajarannya. Mempelajari ilmu kimia tidak hanya bertujuan menemukan zat-zat baru yang langsung bermanfaat bagi kesejahteraan umat manusia belaka, akan tetapi ilmu

\footnotetext{
${ }^{4}$ Rody Putra Sartika adalah Dosen Prog. Studi Pendidikan Kimia FKIP Untan
} 
kimia dapat pula memenuhi keinginan seseorang untuk memahami berbagai peristiwa alam yang ditemukan dalam kehidupan sehari-hari, mengetahui hakikat serta perubahannya, menanamkan metode ilmiah, mengembangkan kemampuan dalam mengajukan gagasan dan memupuk ketekunan serta ketelitian kerja (Depdiknas, 2003:7).Selama ini mata pelajaran kimia masih dianggap sebagai salah satu mata pelajaran yang sulit bagi siswa, karenakimia merupakan mata pelajaran yang banyak mempelajari konsep abstrak(Adaminata \& Marsih, 2011).

Keabstrakan ini ditambah dengan adanya konsep yang berlawanan dengan intuisi menjadikan kimia sebagai pelajaran yang kompleks, sehingga menyebabkan banyak kesulitan bahkan miskonsepsi pada siswa. Materi koloidmerupakan salah satunya materi yang dapat menyebabkan siswa mengalami kesulitan bahkan miskonsepsi, misalnya dalam memahami sifatsifat koloid di dalam kehidupan sehari-hari. Siswa selama ini hanya memahami materi iniberdasarkan fenomena-fenomena yang tampak saja, contohnya penambahan deterjen pada saat mencuci pakaian akan membuat pakaian yang semula kotor menjadi bersih. Fenomena ini dapat diamati dengan tidak adanya noda di pakaian setelah dicuci dan air cucian yang menjadi keruh,akan tetapi ketika diminta untuk menjelaskan mengapa fenomena tersebut terjadi, banyak siswa yang belum bisa menjelaskannya, sehingga diperlukan strategi pembelajaran yang dapat membantu siswa dalam memahami materi kimia yang abstrak.

Pergeseran paradigma yang terjadi pada abad 21 dari penggunaan pendekatan behavioristik menjadi pendekatan konstruktivis di dalam pembelajaran dan mulai diterapkannya kurikulum 2013 di sekolah-sekolah, menuntut penggunaan strategi pembelajaran dimana siswa diajak lebih memahami fenomena alam yang diamati secara ilmiah dengan cara membangun konsep-konsep sendiri dan dapat memberikan penjelasan dari fenomena-fenomena tersebut. Menurut Talib, Matthews, \& Secombe(2005) banyak peneliti percaya konstruktivisme dapat memfasilitasi strategi pengajaran baru di bidang pendidikan sains, untuk mengatasi kritikan dari pendekatan konvensional, yang lebih mengandalkan hafalan dan pembacaan fakta-fakta ilmiah daripada memahami fakta-fakta.Strategi pembelajaran dengan pendekatan konstruktivis yang dapat digunakan di dalam pembelajaran kimia salah satunya adalah model siklus belajar (learning cycle/LC). Pada model siklus belajar siswa dapat membangkitkan pemahamannya sendiri didasarkan pada latar belakang, sikap, kemampuan dan pengalamnnya. Siswa memilih informasi yang disajikan dan prakonsepsi mereka menentukan informasi mana yang menarik perhatiannya, kemudian secara aktif otak menterjemahkan dan menggambarkan kesimpulan berdasarkan informasi yang 
telah disimpan, dengan demikian belajar merupakan suatu proses yang berputar (siklus) (Susiwi, 2007).

Siklus belajar adalah suatu model pembelajaran yang berpusat pada siswa (Simatupang, 2008), dimana setiap fase memiliki fungsi khusus dan memberikan kontribusi untuk pembelajaran yang jelas bagi guru dan rumusan pemahaman yang lebih baik bagi siswa tentang pengetahuan ilmiah dan teknologi, sikap, dan keterampilan (Byber, Taylor, Gardner, Pamela Van Scotter, \& Landes, 2006). Menurut Hanuscin \& Lee (2008) pendekatan pengajaran ini berbasis penyelidikan didasarkan pada tiga tahap yang berbeda: 1) Eksplorasi, yang menyediakan siswa pengalaman langsung dengan fenomena ilmu pengetahuan, 2) Pengenalan konsep, yang memungkinkan siswa untuk membangun pemahaman konsep ilmu pengetahuan melalui interaksi dengan teman sebaya, teks, dan guru, dan 3) Aplikasi konsep, yang mengharuskan siswa untuk menerapkan pemahaman mereka terhadap situasi baru atau masalah baru.

Model siklus belajar terdiri atas lima fase pembelajaran yang meliputi: Engagement, Exploration, Explanation, Elaboration, dan Evaluation(Lorsbach, 2002). Pada model siklus belajar siswa dapat mengidentifikasi suatu pola keteraturan dalam fenomena yang diselidiki, kemudian memperkenalkan konsep-konsep yang ada hubungannya dengan fenomena yang diselidiki dan mendiskusikannya dalam konteks apa yang telah diamati, selanjutnya menggunakan konsep-konsep yang telah diperkenalkan pada situasi baru. Siklus belajar merupakan model pembelajaran berbasis penelitian yang dapat membantu siswa mengeksplorasi konsep dalam sains dan membantu para guru saat mereka merencanakan pelajaran yang dimaksudkan untuk fasilitasi yang bermakna dan pemahaman yang mendalam mengenai konsep yang diajarkan (Duran, Duran, Haney, \& Scheuermann, 2011).

Pada penerapan di kelas, model ini dirangkai dalam lima fase kegiatan. Fase engagement dilakukan dengan membuat koneksi ke pengalaman masa lalu dan mengekspos miskonsepsi siswa dan mereka harus mengurangi ketidakseimbangan kognitif yang terjadi. Pada kegiatan ini guru mengakses pengetahuan siswa dan membantu mereka menjadi terlibat dalam sebuah konsep baru melalui penggunaan aktivitas singkat yang mendorong rasa ingin tahu dan menimbulkan pengetahuan sebelumnya. Kegiatan ini membuat hubungan antara pengalaman belajar masa lalu dan sekarang, terlebih dahulu mengungkapkan konsepsi, dan mengatur pemikiran siswa terhadap aktivitas hasil belajar saat ini.

Fase exploration dilakukan dengan membangun pengalaman guru dan siswa yang dapat digunakan kemudian untuk memperkenalkan dan 
mendiskusikan konsep, proses, atau keterampilan. Pengalaman eksplorasi memberikan siswa sebuah dasar aktivitas umum dimana konsep saat ini (yaitu, miskonsepsi), proses, dan keterampilan yang diidentifikasi dan perubahan konseptual yang difasilitasi. Siswa dapat menyelesaikan kegiatan laboratoriumyang membantu mereka menggunakan pengetahuan sebelumnya untuk menghasilkan ide-ide baru, mengeksplorasi pertanyaan dan kemungkinan, serta desain dan melakukan penyelidikan awal.Lembar Kerja Siswa (LKS) dapat digunakan pada fase ini untuk membantu proses awal merumuskan konsep yang memadai dan akurat. Menurut Cooperstein \& Kocevar Weidinger (2004) konsep-konsep abstrak menjadi berarti, ditransfer, dan disimpan karena mereka terikat dengan kinerja dari suatu kegiatan. Kegiatan pada fase exploration dapat mengarahkan pada penemuan konsep yang diajarkan dan dapat membangun makna dari konsep tersebut.

Fase explanation dilakukan dengan meminta siswa menjelaskan pengalaman eksplorasi dan pengalaman engagement mereka dengan menggunakan istilah umum. Tahap Penjelasan memfokuskan perhatian siswa pada aspek tertentu dari engagement dan pengalaman eksplorasi serta memberikan kesempatan untuk menunjukkan pemahaman konseptual mereka, keterampilan proses, atau perilaku. Fase ini juga memberikan kesempatan bagi guru untuk langsung memperkenalkan konsep, proses, atau keterampilan. Siswa menjelaskan pemahaman mereka tentang konsep.Penjelasan dari guru dapat membimbing mereka ke arah pemahaman yang lebih dalam, yang merupakan bagian penting dari fase ini.Media pembelajaran dapat digunakan pada fase explanation untuk memperoleh dan mengembangkan penjelasan siswa ke arah pemahaman yang lebih mendalam. Menurut Sudjana (2009) media pengajaran dapat mempertinggi proses belajar siswa dalam pengajaran yang pada gilirannya diharapkan dapat mempertinggi hasil belajar yang dicapainya.Penelitian mendukung manfaat dari memanipulasi model fisik dapat membantu siswa untuk memvisualisasikan atom dan molekul serta meningkatkan pemahaman jangka panjang (Barnea \& Dori, 1996; Copolo \& Hounshell, 1995; Gabel \& Sherwood, 1980; Talley, 1973 dalam Wu, Krajcik, \& Soloway (2000).

Fase elaboration dilakukan dengan melibatkan siswa dalam situasi baru dan masalah yang memerlukan transfer penjelasan yang indentik atau mirip. Guru memberikan tantangan dan memperluas pemahaman konseptual dan keterampilan siswa. Melalui pengalaman baru, siswa mengembangkan pemahaman yang lebih mendalam dan lebih luas serta informasi dan keterampilan yang memadai. Siswa menerapkan pemahaman mereka tentang konsep dengan melakukan kegiatan tambahan.Fase evaluation dilakukan 
dengan memberikan penilaian terhadap pengetahuan, pemahaman konsep, atau kompetensi siswa dalam konteks baru yang kadang-kadang mendorong siswa belajar melakukan investigasi lebih lanjut, dengan cara refleksi pelaksanaan pembelajaran.Tahap evaluasi mendorong siswa untuk menilai pemahaman dan kemampuan mereka dan memberikan kesempatan bagi guru untuk mengevaluasi kemajuan siswa untuk mencapai tujuan pendidikan.Menurut (Fajaroh \& Dasna, 2007) penerapan strategi ini memberi keuntungan meningkatkan motivasi belajar karena siswa dilibatkan secara aktif dalam proses pembelajaran.Berdasarkan penjelasan di atas, peneliti melakukan penelitian tentang implementasi model siklus belajar 5Eberbantuan multimediapada materi koloid terhadap respon siswa.

\section{METODE PENELITIAN}

Penelitian ini termasuk penelitian pra-eksperimen, karena memberikan perlakuan model siklus belajar 5E berbantuan multimedia pada materi koloid untuk mengetahui respon siswa terhadap pembelajaran.Penelitian ini melibatkan 79 siswa SMAN 7 Pontianakyang terbagi ke dalam 3 kelas, di mana setiap kelas diberikan perlakuan yang sama. Desain penelitian menggunakan one-shotcase study design.Teknik pengumpulan data yang digunakan di dalam penelitian ini adalah komunikasi tak langsung dengan instrumen yang digunakan berupa angket, di mana pengolahan data hasil penelitian mengunakan skala Likert.

\section{HASIL DAN PEMBAHASAN}

Respon siswa diperoleh dari angket respon yang terdiri atas 25 pertanyaan,diberikan kepada siswa setelah diberikan perlakuan menggunakan model siklus belajar 5E berbantuan multimedia pada materi koloid. Pertanyaan di dalam angket respon siswa secara umum dibagi ke dalam 11 bagian yang meliputi: respon siswa terhadap guru dalam menyampaikan pembelajaran, respon siswa terhadap manfaat dari pembelajaran, respon siswa terhadap materi yang diajarkan, respon siswa terhadap tingkat keberhasilan yang diperoleh setelah pembelajaran, respon siswa terhadap tugas yang diberikan dalam pembelajaran, respon siswa terhadap model pembelajaran yang digunakan, respon siswa terhadap kerja kelompok di dalam pembelajaran, respon siswa terhadap buku siswa yang diberikan dalam pembelajaran, respon siswa terhadap kegiatan praktikum dalam pembelajaran, respon siswa terhadap lembar kerja siswa (LKS) yang diberikan dalam pembelajaran dan respon siswa terhadap multimedia yang digunakan dalam pembelajaran. Hasil respon 
siswa terhadap pembelajaran mengunakan model siklus belajar $5 \mathrm{E}$ berbantuan multimedia pada materi koloid dapat di lihat pada Gambar 1



Keterangan item respon:

1. Guru benar-benar mengetahui bagaimana membuat kami menjadi antusias terhadap materi pelajaran.

2. Guru membuat suasana menjadi tegang apabila membangun suatu pengertian/konsep.

3. Rasa ingin tahu saya sering kali tergerak oleh pertanyaan yang dikemukakan dan masalah yang diberikan guru pada materi pembelajaran ini.

4. Guru membuat materi pelajaran ini memang penting.

5. Saya berpendapat bahwa akan memperoleh banyak manfaat dari pembelajaran ini.

6. Manfaat pribadi dari pembelajaran ini jelas bagi saya.

7. Materi pelajaran ini terlalu sulit bagi saya.

8. Di dalam pelajaran ini muncul rasa keingintahuan saya terhadap materi yang diajarkan. 
9. Untuk mencapai tujuan, penting bagi saya untuk berhasil di dalam pembelajaran ini.

10. Saya yakin bahwa saya akan berhasil dalam pembelajaran ini.

11. Saya berpendapat bahwa tingkat tantangan dalam tugas yang diberikan di dalam pembelajaran ini tepat, tidak terlalu gampang dan tidak terlalu sulit.

12. Jumlah tugas yang harus saya kerjakan memadai untuk pembelajaran semacam ini.

13. Pembelajaran menggunakan model siklus belajar membuat saya aktif di dalam kelas.

14. Pembelajaran dengan menggunakan metode siklus belajar memudahkan saya dalam memahami materi yang diajarkan.

15. Pembelajaran menggunakan model siklus belajar hanya membuat saya merasa bosan.

16. Saya merasa senang karena suasana belajar dibentuk dalam kelompok belajar.

Gambar 1. Respon siswa terhadap pembelajaran model siklus belajar berbantuan multimedia

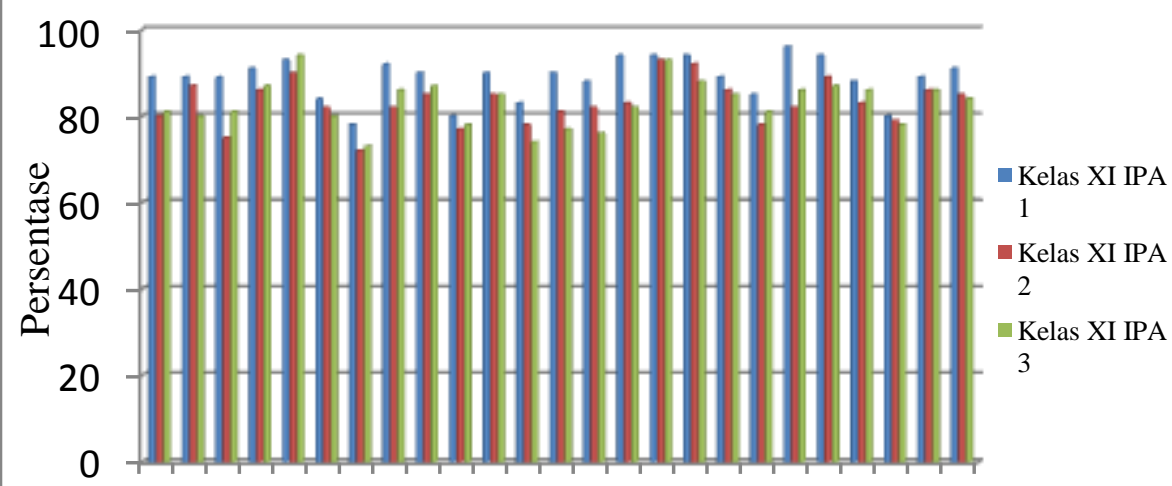

$\begin{array}{lllllllllllll}1 & 3 & 5 & 7 & 9 & 11 & 13 & 15 & 17 & 19 & 21 & 23 & 25\end{array}$

Item respon

17. Kerja kelompok tidak membantu saya dalam memahami materi yang diajarkan.

18. Pemberian buku siswa membantu saya dalam memahami materi yang diajarkan.

19. Materi koloid di dalam buku siswa kurang jelas dan tidak menarik. 
20. Kegiatan praktikum membuat saya aktif dalam pembelajaran.

21. Kegiatan praktikum membuat saya mengetahui manfaat materi koloid dalam kehiduan sehari-hari.

22. Pemberian LKS tidak membantu saya dalam memahami materi yang diajarkan.

23. LKS yang diberikan jelas dan mudah dipahami.

24. Gambar, video dan animasi yang disajikan di dalam media membantu saya memahami materi yang diajarkan.

25. Media pembelajaran yang digunakan membuat saya termotivasi untuk belajar materi yang diajarkan.

Berdasarkan Gambar 1 rata-rata respon yang diberikan siswa pada semua item yang dinilai memberikan persentase $\geq 80$, hal ini berarti bahwa rata-rata sebagian besar siswa memberikan respon yang sangat baik terhadap penerapan pembelajaran menggunakan model siklus belajar 5E berbantuan multimedia pada materi koloid.Menurut Arends (2008) studi-studi tentang kelas dan pengajaran menunjukkan bahwa motivasi dan pembelajaran siswa dipengaruhi oleh proses dan struktur yang diciptakan guru di kelas tertentu. Guru harus mencoba mengupayakan siswa mereka tertarik dengan bahan yang sedang mereka sajikan dan kemudian menyajikannya dengan memikat dan memuaskan maupun meningkatkan keingintahuan siswa tentang bahan itu sendiri (Slavin, 2011).

Rata-rata respon siswa memberikan hasil yang sangat baik terhadap pembelajaran mengunakan model siklus belajar 5E disebabkan karena pada model siklus belajar dapat membangkitkan ketertarikan siswa terhadap materi yang akan dipelajari melalui fase engagement, di mana guru diharapkan membuat suasana belajar menjadi tidak tegang sehingga siswa menjadi antusias dan rasa ingin tahunya meningkat. Fase inimelibatkan siswa dalam tugas belajar, di mana mental siswa berfokus pada obyek, masalah, situasi, atau peristiwa. Kegiatan pada fase ini membuat koneksi ke masa pengalaman lalu dan mengekspos miskonsepsi siswa dan mereka harus mengurangi ketidakseimbangan kognitif yang terjadi.Peran guru adalah menyajikan situasi dan mengidentifikasi tugas pembelajaran.Selain itu, guru juga diharapkan dapat meyakinkan siswa bahwa materi yang pelajari penting dan bermanfaat bagi mereka. Penting meyakinkan siswa tentang kadar daya tarik bahan yang akan disajikan, untuk memperlihatkan (jika mungkin) betapa pengetahuan yang akan diperoleh akan bermanfaat bagi siswa (Bergin, 1999).

Model siklus belajar juga dapat mempertahankan keingintahuan siswa melalui fase exploration dan fase elaboration. Kegiatan eksplorasi dirancang sedemikian rupa sehingga siswa di kelas memiliki kesamaan pengalaman konkret dimana mereka terus merumuskan konsep, proses, dan keterampilan. 
Pada fase engagementmembawa siswa pada proses ketidakseimbangan, sedangkan fase exploration memulai proses keseimbangan. Fase elaboration memfasilitasi transfer konsep untuk situasi sama yang terkait tetapi baru. Pada beberapa kasus, siswa masih mungkin memiliki miskonsepsi, atau mereka hanya dapat memahami konsep dalam hal pengalaman eksplorasi. Kegiatan elaborasi menyediakan waktu lebih lanjut dan pengalaman yang mendukung proses belajar. Kedua fase tersebut guru membagi siswa ke dalam beberapa kelompok heterogen dan memberikan LKS kepada masing-masing kelompok yang berisikan tugas-tugas yang digunakan untuk menuntun siswa dalam menemukan konsep yang dipelajari dan memberikan pengalaman langsung kepada siswa. Menurut Guthrie dan Cox (2001) dalam Slavin (2011) pemberian pengalaman langsung ke kegiatan ilmu pengetahuan alam kepada siswa sangat meningkatkan pembelajaran mereka dari buku tentang topik terkait dan memberikan lebih banyak motivasi.

Penggunaan penyajian yang menarik pada model siklus belajar dapat dilakukan pada fase explanation untuk membimbing siswa ke arah pemahaman konsep yang lebih mendalam melalui pemberian buku siswa dan penggunaan multimedia dalam menjelaskan konsep-konsep yang abstrak. Menurut Slavin (2011) Motivasi intrinsik untuk mempelajari sesuatu akan meningkat melalui penggunaan bahan yang menarik, dan juga berbagai jenis cara penyajian. Pada fase ini, guru mengarahkan perhatian siswa terhadap aspek-aspek tertentu dari engagement dan pengalaman eksplorasi. Pertama, guru meminta siswa untuk memberikan penjelasan mereka,kedua, guru memperkenalkan penjelasan ilmiah atau teknologi secara langsung, eksplisit, dan formal. Guru harus mendasarkan bagian awal dari fase ini pada penjelasan siswa dan secara jelas menghubungkan penjelasan dengan pengalaman dalam fase engagement danexploration.

Fase evaluation digunakan guru untuk menilai pemahaman konsep siswa. Siswa diharapkan dapat menentukan tingkat keberhasilan dari pembelajaran yang mereka laksanakan. Menurut Ryan dan Deci (2000) salah satu prinsip mendasar motivasi ialah bahwa orang bekerja lebih keras demi sasaran yang mereka tentukan sendiri daripada sasaran yang ditentukan orang lain bagi mereka. Fase ini adalah kesempatan penting bagi siswa untuk menggunakan keterampilan yang telah mereka peroleh dan mengevaluasi pemahaman mereka. 


\section{SIMPULAN}

Berdasarkan hasil penelitian dan pembahasan di dalam penelitian, dapat disimpulkan bahwa responsiswa sangat baik pada pembelajaran menggunakan model siklus belajar 5Eberbantuan multimediapada materi koloid.

\section{DAFTAR PUSTAKA}

Adaminata, M. A., \& Marsih, I. N. (2011, September 23). Analisis Kesalahan Konsep Siswa SMA pada Pokok Bahasan Kesetimbangan Kimia. Retrieved Januari 27, 2013, from google.com: http://portal. fi.itb.ac.id/cps/

Arends, R. L. (2008). Learning To Teach Edisi Ketujuh. Yokyakarta: Pustaka Pelajar.

Bergin, D. A. (1999). Influences on Classroom Interest. Educational Psychologist, 87-98.

Byber, R. W., Taylor, J. A., Gardner, A., Pamela Van Scotter, J. C., \& Landes, N. (2006). The BSCS 5E Instructional Model: Origins and Effectiveness. Colorado Springs: BSCS.

Cooperstein, S. E., \& Kocevar Weidinger, E. (2004). Beyond Active Learning: a Constructivist Approach to Learning. Emerald Group Publishing Limited, 141-148.

Depdiknas. (2003). Kurikulum 2004 Standar Kompetensi Mata Pelajaran Kimia SMA dan MA. Jakarta: Departemen Pendidikan Nasional.

Duran, E., Duran, L., Haney, J., \& Scheuermann, A. (2011). A Learning Cycle for All Student. Ohio: Sci Links.

Fajaroh, F., \& Dasna, I. W. (2007, September 20). PEMBELAJARAN DENGAN MODEL SIKLUS BELAJAR (LEARNING CYCLE).Retrieved Oktober 2013， 3, from http://lubisgrafura. wordpress.com:

http://lubisgrafura.wordpress.com/2007/09/20/pembelajaran-denganmodel-siklus-belajar-learning-cycle/

Hanuscin, D. L., \& Lee, M. H. (2008). Using the Learning Cycle as a Model for Teaching the Learning Cycle to Preserve Elemtary Teacher. Journal of Elementary Science Education, Vol. 20. No. 2, 5166.Lorsbach, A. (2002). The Learning Cycle as A Tool for Planning Science Instruction. Retrieved Desember 10, 2002, from http://www.coe.ilstu.edu/scienceed/lorsbach/257lrcy.html.

Ryan, R. M., \& Deci, E. L. (2010). Intrinsic and Extrinsic Motivations: Classic Definitions and New Directions. Educational Psychology, 54-67. 
Simatupang, D. (2008). Pembelajaran Model Siklus Belajar (Learning Cycle). Jurnal Kewarganegaraan, 62-70.

Slavin, R. E. (2011). Psikologi Pendidikan Teori dan Praktik Edisi Kesembilan. Jakarta: PT Indeks.

Sudjana, N. (2009). Media Pengajaran (Penggunaan dan Pembuatannya). Bandung: Sinar Baru Algensindo.

Susiwi. (2007). Siklus Belajar Suatu Model dalam Pembelajaran Kimia "Handout". Retrieved Mei 30, 2013, from http://file.upi.edu: http://file.upi.edu/Direktori/FPMIPA/JUR._PEND._KIMIA/19510919 1980032-SUSIWI/SUSIWI27)._HANDOUT_SIKLUS_BELAJAR.pdf

Talib, O., Matthews, R., \& Secombe, M. (2005). Constructivist Animation: A Promosing Alternative Tool in Bridging Theory - Practice Gap in Science Education. Retrieved Juni 4, 2013, from http://www.recsam.edu.my/cosmed/cosmed05/AbstractsFullPapers200 5/files\%5Csubtheme3\%5COT.pdf: http://www.google.com.

Wu, H. k., Krajcik, J. S., \& Soloway, E. (2000). Promoting Conceptual Understanding of Chemical Representations: Students' Use of a Visualization Tool in the Classroom. New Orleans, LA.: Paper presented at the annual meeting of the National Association of Research in Science Teaching, April 28-May 1, 2000. 